\title{
Intense transmission of visceral leishmaniasis in a region of northeastern Brazil: a situation analysis after the discontinuance of a zoonosis control program
}

\author{
Transmissão intensa da Leishmaniose Visceral em região do Nordeste \\ do Brasil: uma análise após a descontinuidade do programa \\ de controle de zoonoses
}

\author{
Ranielly Araujo Nogueira; Maria Gabriela Sampaio Lira'; Sarah Ingrid Pinto Santos²; \\ Renata Mondêgo-Oliveira ${ }^{3}$; Fábio Henrique Evangelista de Andrade4; Eduardo Martins de Sousa5; \\ David Soeiro Barbosa6; Ana Lucia Abreu-Silva ${ }^{1,2}$; Rafael Cardoso Carvalho ${ }^{\text {* }}$ (1)

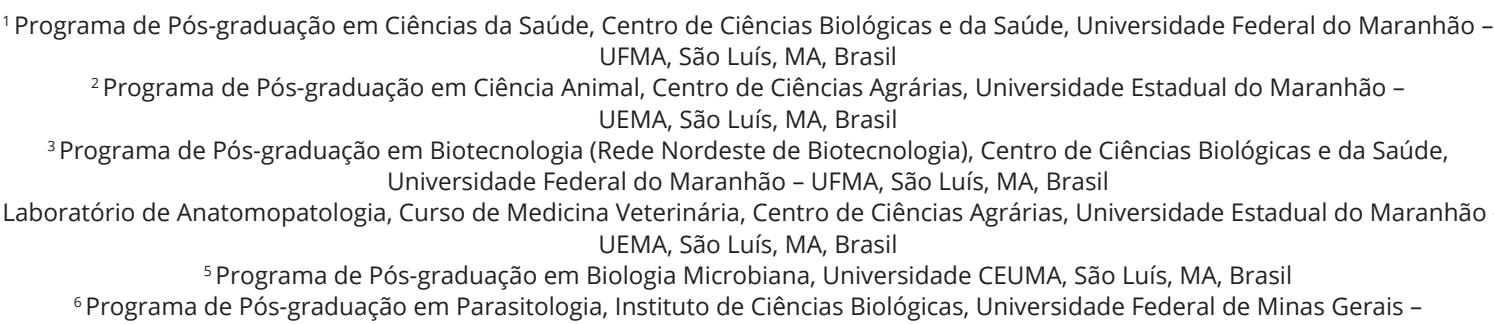

How to cite: Nogueira RA, Lira MGS, Santos SIP, Mondêgo-Oliveira R, de Andrade FHE, de Sousa EM, et al. Intense transmission of visceral leishmaniasis in a region of northeastern Brazil: a situation analysis after the discontinuance of a zoonosis control program. Braz J Vet Parasitol 2021; 30(1): e020320. https://doi.org/10.1590/S1984-29612021015

\begin{abstract}
In São Luís, Maranhão, northeastern Brazil, the notification of visceral leishmaniasis (VL) cases intensified in 1982, showing endemic and epidemic patterns. In this city, the Center for Zoonoses Control (CZC) was an organization in charge of the control and prevention of the disease. However, technical and political reasons have led to a significant decline in the periodicity of its activities. Therefore, in this study we evaluated the epidemiological scenario of human visceral leishmaniasis (HVL) and the prevalence of the disease in dogs after the cessation of the CZC activities, covering the period of 2007 to 2016. The seroprevalence of canine leishmaniasis was determined based on clinical and serological profiles. HVL cases were notified using data provided by the Municipal Health Department of São Luís. A seropositivity rate of 45.8\% ( $p=0.0001)$ was found among dogs, $54 \%(p=0.374)$ of which were asymptomatic. As for human cases, there were 415 notifications, with an increase in the incidence of the zoonosis observed during the aforementioned period. Thus, it can be inferred that after the control and surveillance activities were curtailed, there was an increase in the number of seropositive animals in circulation, acting as reservoirs of infection for dogs and humans.
\end{abstract}

Keywords: Endemic, Leishmania, state of Maranhão, public policies, zoonosis.

\section{Resumo}

Em São Luís, Maranhão, região Nordeste do Brasil, a notificação de casos de Leishmaniose Visceral (LV) intensificou-se em 1982, com padrão epidêmico e endêmico. Nessa cidade, o Centro de Controle de Zoonoses (CCZ) era uma entidade que realizava ações de controle e prevenção da doença, mas, nos últimos anos, a periodicidade de suas atividades reduziram-se significativamente, devido a diversos fatores técnico-políticos. Portanto, neste estudo avaliou-se o cenário epidemiológico da leishmaniose visceral humana (LVH) e a prevalência da doença em cães, após a descontinuidade das atividades do CCZ, no período de 2007-2016. A soroprevalência canina

Received October 5, 2020. Accepted February 4, 2021

*Corresponding author: Rafael Cardoso Carvalho. E-mail: carvalho.rafael@ufma.br 
foi determinada de acordo com o perfil clínico e a sorologia. Os casos notificados de LVH foram realizados a partir de dados da Secretaria Municipal de Saúde de São Luís. Observou-se frequência de 45,8\% ( $p=0,0001)$ de cães soropositivos, dos quais $54 \%$ ( $p=0,374)$ eram assintomáticos. Em relação aos casos humanos, ocorreram 415 notificações, com aumento na incidência das zoonoses observada no período. Assim, pode-se inferir que, com a interrupção das atividades de controle e vigilância, houve um grande número de animais circulantes positivos, atuando como fonte de infecção tanto para cães quanto para humanos.

Palavras-chave: Endemia, Leishmania, Estado do Maranhão, políticas públicas, zoonose.

\section{Introduction}

Visceral leishmaniasis (VL) is considered one of the most important endemic parasitic diseases from the standpoint of global public health, affecting mainly the poorest populations and those in situations of social and economic vulnerability (Alvar et al., 2006). It is an infectious, non-contagious and chronic disease caused by obligate intracellular protozoan parasites of the genus Leishmania found in the tropics, subtropics, and temperate regions (Alvar et al., 2012).

From a global perspective, Brazil is one of the main foci of $\mathrm{VL}$, with an average annual incidence of 2 cases per 100,000 inhabitants in 2017 (Sinan, 2018). In that year, the country had 3,987 confirmed cases (Sinan, 2019a), and among the country's states, Minas Gerais and Maranhão presented the highest numbers, with 781 and 709 cases, respectively (Sinan, 2019b,c).

Dogs are considered the main domestic reservoirs of $L$. infantum and the main source of infection by the vector. Therefore, the presence of these animals in endemic areas is a risk factor for the development of human disease (Alves \& Bevilacqua, 2004).

In order to reduce the spread of the disease and mortality rates, the Ministry of Health established a Visceral Leishmaniasis Surveillance and Control Program, whose activities are based on three strategies: early diagnosis and treatment of human patients, vector control through environmental management and use of insecticides, and identification and culling of infected dogs (Brasil, 2014). However, despite the efforts and resources spent on the management of the program, it is clear that the actions aimed at reducing transmission did not have the desired effect (Werneck, 2016).

In the state of Maranhão, VL is endemic and represents one of the main public health problems with a large number of infected dogs and humans and no effective measures for controlling the disease or reducing the number of cases (Barbosa, 2011; Costa et al., 1995, 2015). In the state capital, São Luís, the Center for Zoonoses Control (CZC) carried out prevention and control measures related to LV reservoirs, but despite these interventions, high prevalence rates were recorded over the years (Abreu-Silva et al., 2008; Barbosa et al., 2010).

For many years, the population denigrated the image of the CZC, associating it only with the capture and euthanasia of animals. However, its functions have changed over the years (FUNASA, 2003). The CZC in São Luís was established in 1988 to perform predetermined functions, such as the control and capture of animals infected with Leishmania.

After 25 years, in 2013 the CZC facilities in São Luís were legally banned due to the lack of proper structural conditions to house animals. However, before the CZC services were overhauled and its facilities expanded, the agency was asked to move to another address. As a result, the construction was halted, as were the animal capture services, leading to an increased risk of proliferation of $\mathrm{VL}$ and other zoonotic diseases.

Finally, the CZC now renamed the Surveillance of Zoonoses Unit (SZU) was relocated to a new building in 2016 and its activities restarted. However financial and structural limitations remained, preventing the new unit from carrying out activities to control VL and other zoonotic diseases on a regular basis. Nevertheless, the ZSU offers some services such as the diagnosis of seropositive animals through passive.

Due to the continuous and increased reporting of cases of the disease in São Luís, we tested the hypothesis that the interruption of surveillance and control services provided by the CZC led to an increase of VL cases in the city. Thus, one of the aims of this study was to assess the epidemiological situation of the disease in humans in the period of 2007 to 2016. Another goal was to garner data on the prevalence of CVL during 2013-2016, after the activities and public policies of the CZC were discontinued. This was achieved by conducting a serological survey to identify silent transmission and delimit areas that require the implementation of control measures. 


\section{Methods}

\section{Ethical aspects}

The use of animals in this research was approved by the Committee on Animal Research and Ethics of the State University of Maranhão - UEMA (under Protocol no. 030/2015), and the use of human data was approved by the Research Ethics Committee of the University Hospital of the Federal University of Maranhão UFMA (Resolution no. 2453899).

\section{Study area}

The study was conducted in the city of São Luís, Maranhão, covering an area of $834.78 \mathrm{~km}^{2}$ and with an estimated human population of 1,091,868 in 2017 (IBGE, 2018). According to administrative and planning criteria of the Municipal Health Department, São Luís is divided into seven health districts: Centro, Itaqui-Bacanga, Coroadinho, Cohab, Bequimão, Tirirical and Vila Esperança. The district of Tirirical was selected for the canine survey sample, as it is an area endemic for $\mathrm{VL}$, with numerous human and canine cases of visceral leishmaniasis reported in previous studies (Abreu-Silva et al., 2008; Barbosa et al., 2010).

Four neighborhoods were chosen in the selected district (Cidade Operária, Cidade Olímpica, Jardim América and São Cristóvão), based on their urban characteristics and the presence of community centers or residents' associations, to garner information about infections and to diagnose the disease among dogs.

\section{Temporal analysis of the occurrence of $\mathrm{HVL}$}

The epidemiological survey of human cases notified in São Luís was based on records obtained by the Superintendence of Epidemiological and Sanitary Surveillance of the Municipal Health Department. The data recorded in the period of 2007 to 2016 were plotted.

Incidence rates were calculated based on reported human cases, using the population estimate published by the Brazilian Institute of Geography and Statistics - IBGE as the denominator (estimated population of 1,091,868 inhabitants in 2017) (IBGE, 2018), multiplied by 100 thousand inhabitants. As inclusion criteria, only cases of people residing in the city were selected, notified during the established period, considering the district of residence.

\section{Collection of blood samples for the canine survey}

The number of samples for studies to estimate prevalence was calculated as established by the Pan American Zoonoses Center (CEPANZO, 1979), and 190 samples of canine blood were collected. The following exclusion criteria were: dogs not domiciled in the selected neighborhoods, stray dogs, dogs under six months old due to the incubation period of the disease (Brasil, 2014), and dogs whose owners did not sign the free informed consent form.

\section{Educational and diagnostic actions for CVL}

At this stage of the study, educational activities were carried out in the selected neighborhoods and free tests for CVL diagnosis were offered. The educational actions consisted of the distribution of flyers, posters, and mobile audio ads. This publicity was followed by talks with the local population to clarify doubts about the disease, such as clinical signs, mechanisms of transmission and prophylactic measures.

After raising the awareness and sensitizing the public, clinical evaluations and blood sampling of dogs were carried out. The clinical examination of the dogs started by the owner filling out the dog's medical record, which included 14 clinical signs. The clinical form had a score of 0 to 19 and was filled out according to the severity, presence, or absence of clinical signs (Silva et al., 2017). The clinical examination was performed in appropriated locations on community associations of Tirirical District by veterinarians. The clinical chart presented general clinical signs, like apathy, presence of ectoparasites, hemorrhages, nutritional status, size of lymph nodes, as well as cutaneous and ocular manifestations.

Thus, animals with scores equal to or above four (4) and reactive serology for Leishmania were considered symptomatic. Those with reactive serology but with a score between 0 and 3 were classified as asymptomatic. The study performed by Silva et al. (2017) served as a basis for evaluating these parameters. 
After the clinical evaluation, $5 \mathrm{~mL}$ of blood were drawn into tubes without anticoagulant for serological analysis. The samples were refrigerated and taken to the Pathology Laboratory of the State University of Maranhão. At the lab, the samples were left at room temperature until complete clot retraction, followed by centrifugation at $252 \mathrm{G}$ for 15 minutes. The resulting serum was placed in propylene tubes and stored at $-20^{\circ} \mathrm{C}$ until the moment of serological testing.

Serological analysis was performed based on the enzyme-linked immunosorbent assay (ELISA), using the ELISA/S7 ${ }^{\circledR}$ kit (Biogene ${ }^{\circledR}$ ) as per the manufacturer's instructions. Seroreactive animals were classified as symptomatic (reagent test and clinical score $\geq 4$ ) and asymptomatic (reagent tes $t$ and clinical score ranging from 0 to 3 ). After obtaining the serological results, the owners were notified and given advice about treatment, according to the diagnosis.

\section{Statistical analysis}

The results were analyzed by the Chi-square and Fisher's exact tests. Statistical analyses were performed with Stata14 software and differences were considered significant when $p<0.05$.

\section{Results and Discussion}

\section{Temporal analysis of the occurrence of HVL}

Between 2007 and 2016, 415 cases of HVL were confirmed and notified to the Information System for Notifiable Diseases (SINAN), with an average of 41.5 cases/year. As can be seen in Figure 1, the number of reported cases between 2008 and 2012 declined in comparison to 2007. However, from 2013, when the activities of the CZC were suspended, there was an increase in reported HVL cases, and hence, a high incidence coefficient. It should be noted that the state of Maranhão has been considered a high risk area for VL since 2001, and that the disease incidence coefficient increased (Azevedo et al., 2019) during the period when the CZC activities in São Luís were suspended.

The incidence of VL in São Luís fluctuated over the years, but incidence rates between 2000 and 2016 did not reach the 15.8 cases per 100,000 inhabitants recorded in 1999, when the disease reached an epidemic peak. According to Barbosa (2011), after this epidemic peak, the disease rates decreased until 2002, followed by two years of an upward trend and then a downward trend between 2005 and 2007. The findings reported by Barbosa (2011) and our results indicate that the incidence of the disease remained low until the interruption of the activities of the CZC, which was responsible for controlling the main reservoirs of the disease in the city.

Among the analyzed cases, $66.7 \%$ (277/415) were male, which was the case in the studies of Barbosa (2011) and Silva et al. (2008). As for the age groups of affected individuals, 48.9\% (203/415) were children

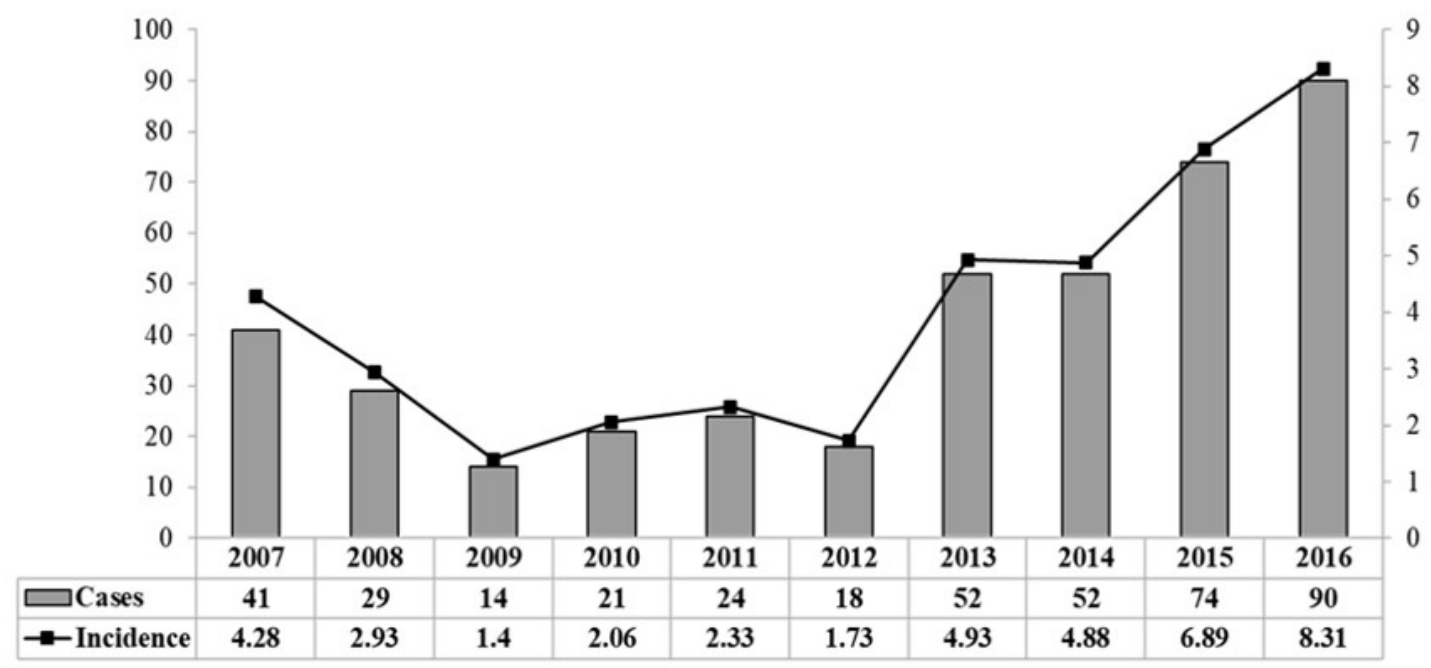

Figure 1. Distribution of the number of cases and incidence of human visceral leishmaniasis (HVL) during 10 years in São Luís, MA. Incidence per 100,000 inhabitants (Source: São Luís Municipal Health Secretary). 
up to nine years old. Although the disease affects people of all ages, 41.9 to $80 \%$ of recorded cases occur in children under 10 years of age (Marcondes \& Rossi, 2013). VL is considered a fatal disease when not treated in time (Alvar et al., 2012).

Co-infection is another important aspect can be highlight as factors associated with the increased incidence of VL. According to Lindoso et al. (2018), VL-HIV co-infection is a major problem in Brazil and tuberculosis can contribute to a high mortality in VL-HIV co-infection (up to $25 \%$ ). However, these authors stressed that the evidence on the prevalence and clinical impact of tuberculosis on VL-HIV co-infection is still limited.

Consequently, we understand the value of these variables, so we searched for the data available on SINAN (Information System of Notifications Grievances), a platform linked to the Brazilian Ministry of Health, whose information is provided by states and municipal agencies. When analyzing the data available in this platform in the period between 2008 and 2016, 68 cases of VL/HIV comorbidity were recorded for the city of São Luís. However, several factors can be highlighted, such as the failure to fill this variable in the investigation form or registration in the notification system.

In our study, with data obtained directly from the Municipal Health Department, we also observed the absence of filling in the form or registration in the system, when noting that $24.8 \%(p=0.001)$ of the 415 cases did not have the district of origin [data not shown]. It demonstrates a statistically significant failure in this service, as from the registration of the patient's home, the responsible agencies could carry out epidemiological investigations and therapeutic conduct. We also observed that, between 2007 and 2009, there are a large number of unregistered cases regarding the district's origin $(n=63)$, and only after 2010 was it possible to observe an improvement in the registration regarding this type of information [data not shown]. Therefore, there is a possibility that the same happens with the SINAN data.

Of the reported cases in São Luís, there was a clinical cure rate of 75.7\% (314/415) and a mortality rate of $6.5 \%(27 / 415)$. Mortality, in this case, may be associated with several factors, such as the evolution of the disease, symptoms, access to health services, associated comorbidities, treatment dropout and relapses. Some of these factors were associated with high mortality rates in the states of Minas Gerais (11.6\%) (Bruhn et al., 2018) and in São Paulo (14.1\%) (Madalosso et al., 2012).

The district of Tirirical was the first among the seven health districts in São Luís to record the occurrence of human and canine cases of VL (Barbosa et al., 2010), and it is still the location with the highest records of the disease, together with the district of Vila Esperança (Figure 2). For nine years, no cases had been notified in the Centro district (Barbosa, 2011). However, in our analysis, 21 cases were reported, with the year 2016 presenting the highest number of cases (13), which suggests an intensification of the urbanization of the disease in this city.

It was observed that $24.8 \%(103 / 415 ; p=0.001)$ of the notified cases lacked information about the health district in which the patient lives, which is a failure, since this information allows for better targeting of surveillance and

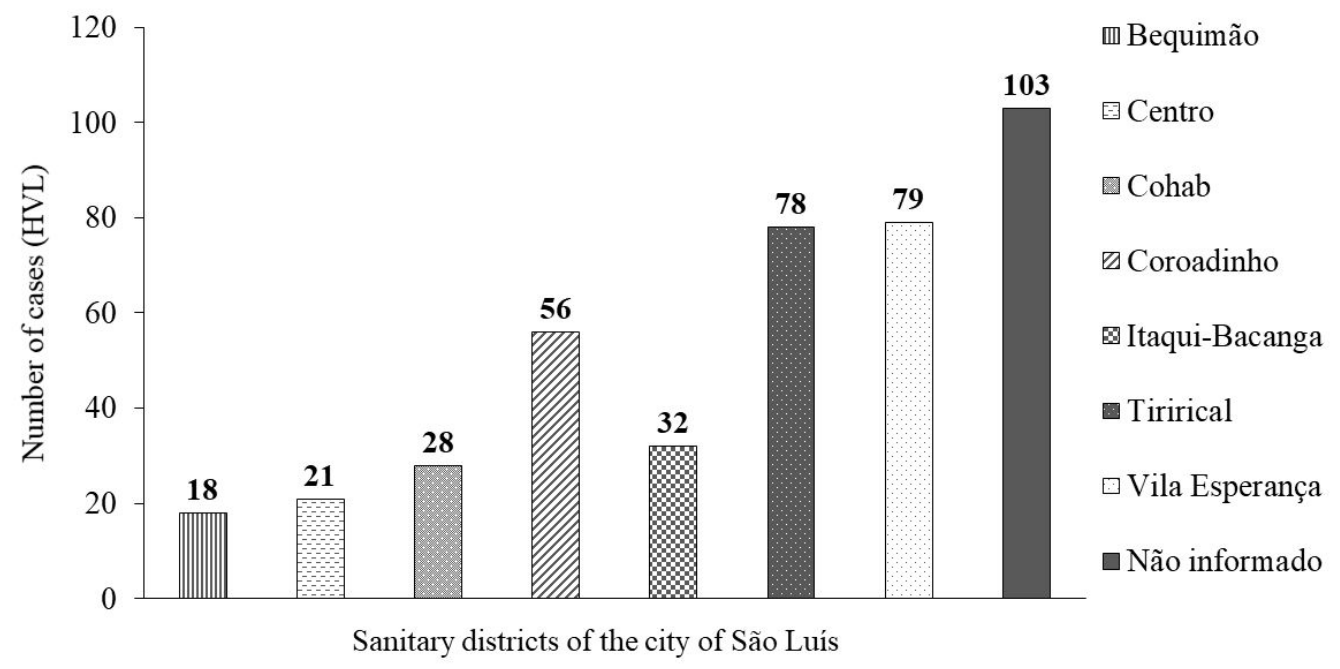

Figure 2. Distribution of notified cases of human visceral leishmaniasis (HVL), between the years 2006 to 2016, in São Luís, MA by health district (Source: São Luís Municipal Health Secretary). 
control actions by the agencies in charge. There are many neighborhoods in the district of Tirirical, and population growth leads to expanding demand for land, causing this district to absorb adjacent small towns and squatter land, which then become neighborhoods of this district. Among the 78 cases reported in this district, 15 failed to include the names of the patient's neighborhoods. Of the four neighborhoods selected for the canine sample survey, three presented records of HVL cases in the analyzed period (São Cristóvão, Cidade Operária and Cidade Olímpica).

\section{Canine survey for CVL diagnosis}

Among the 190 analyzed samples, 87 animals, i.e., $45.8 \%(p=0.0001)$ were reactive to Leishmania spp. Of the animals positive for $\mathrm{CVL}$, the largest number lived in the Cidade Operária neighborhood $(n=32 / 45)$. As for sex, $55.2 \%$ of positive animals were male $(48 / 87)$ and $44.8 \%$ were female $(39 / 87)$. With regard to breed, $78.2 \%(68 / 87)$ were mixed breed, and in terms of age, $60.91 \%$ (53/87) were up to 3 years old. Nevertheless, the variables of sex $(p=0.585)$, breed $(p=0.502)$ and age $(p=0.969)$ did not show statistically significant differences.

There is a lively debate in the literature about the importance of these variables in the progression of infection and disease in dogs (Belo et al., 2013; Figueiredo et al., 2014; Julião et al., 2007; Miranda et al., 2008; Toscano et al., 2013). Some studies indicate that sex may represent a risk factor for this infection, and that males are more susceptible to the disease (Dantas-Torres et al., 2006; Julião et al., 2007; Miranda et al., 2008). According to Toscano et al. (2013), Lutzomyia longipalpis performs random hematophagy, and the prevalence of infection depends on the proportion of men and women in the population of each region.

$V L$ can affect animals of any age, but this disease can occur bimodally in dogs: the first peak occurs in animals younger than three years old and the second in animals between two and ten years old (Paltrinieri et al., 2010). França-Silva et al. (2003) and Almeida et al. (2010) state that adult dogs are prone to be more frequently parasitized by Leishmania than young animals. This predisposition is possibly associated with the parasite's incubation period, which can vary from two months to several years (Trotz-Williams \& Gradoni, 2003). Studies have shown significant serological positivity in young dogs, which may be explained by the fact that their immune response is less efficient than that of adult dogs, making them quite vulnerable to infection (Dantas-Torres et al., 2006; Figueiredo et al., 2014). Despite the lack of consensus, studies can determine these variations reflected in the epidemiological role they play in the locations under study (Julião et al., 2007).

Among the dogs examined here, $12.1 \%(23 / 190)$ lived close to forested areas, and 60.9\% (14/23; $p=0.439)$ of them were positive for Leishmania sp. The presence of forested areas, allied to the proximity to poultry farms, the presence of wild animals and poor sanitary conditions, are important factors associated with the occurrence of the disease, and serve as pointers to identify areas of greater risk for the occurrence of canine leishmaniasis (Barbosa et al., 2010; Bigeli et al., 2012; Costa et al., 2015).

In all the areas where canine blood samples were collected, dogs were found showing clinical signs suggestive of CVL, such as onychogryphosis (28.4\%), skin lesions (16.3\%), muzzle and ear injuries (13.2\%), muzzle depigmentation (6.3\%) and blepharitis (5.8\%). Statistically, only the nutritional status characterized as cachexia was significant $(p=0.001)$, showing a greater association of the presence of this sign with the cases of dogs seroreactive for $\mathrm{VL}$ in this study area, although the other signs may also be indicators of the disease. Although VL can be associated with several clinical signs, some dogs may be asymptomatic, which makes the clinical diagnosis of this disease quite difficult (Foglia Manzillo et al., 2013; Manna et al., 2015).

In our study, the population of positive dogs showed a greater number of animals asymptomatic to VL (54\%; 47/87), which had a score less than or equal to four, according to Silva et al. (2017). The clinical score used in this study, according to Silva et al. (2017), helps in the accuracy of results of serological tests. All animals classified as symptomatic or asymptomatic had reagent results confirmed in serological tests for Leishmania sp. Therefore, the combination of the test and the clinical score makes the diagnosis more accurate. Furthermore, only with the association of clinical results with laboratory examination, it is possible to recognize which dogs are asymptomatic or symptomatic, data of extreme relevance in this work.

The p-value associated with the clinical signs found in seropositive dogs only indicates which ones can usually be found in dogs with the disease. It is important to note that all manifestations addressed in this study are associated with VL in the literature, even if common to other parasites (Foglia Manzillo et al., 2013; Manna et al., 2015). Precisely to provide diagnostic accuracy and provide classification data regarding clinical signs. 
Studies by Alvar et al. (2006) and Dantas-Torres et al. (2006) point out that approximately $50 \%$ to $60 \%$ of infected dogs from endemic areas are asymptomatic. Thus, it is extremely important to carry out sample or census surveys, especially in endemic areas, since positive but asymptomatic dogs may go unnoticed.

The weaknesses of the VL surveillance and control program in the city of São Luís were highlighted by Silva et al. (2008). These included lacks of a work plan that would allow for sustainable actions, lack of funding, vehicles, skilled labor and supplies. In addition, the actions of the CZC, such as capture and euthanasia of positive dogs, as well as vector control, were carried out in a disjointed manner. This situation persisted until the complete cessation of the CZC's activities, underscoring the need for political and administrative restructuring of the unit, in addition to the planning and definition of priority areas, so that more effective control actions can be carried out.

Positive correlations between canine and human infections were reported by Vigilato (2004) and Margonari et al. (2006), who found that the greater the number of positive dogs, the greater the number of human cases. Between 1999 and 2007, the health districts of São Luís with the highest number of human cases also had canine cases (Barbosa, 2011). Belo et al. (2013) also associated the increase in the prevalence of CVL with the previous occurrence of VL in humans. A more detailed analysis of the overlapping of human and canine cases could help in the development of more efficient and targeted prophylactic measures for each district. However, such an evaluation could not be carried out because the CZC was unable to provide data on canine cases since 2007, stating that it had not kept such records.

The findings of this study are of great interest and serve as a warning to public health authorities at the municipal and state levels. Thus, it is expected that the agencies responsible for the control of endemic diseases in the city will be warned about the distribution of cases, enabling them to engage in mitigating measures involving canine reservoirs, vectors and health education.

\section{Conclusions}

The number of cases of human and canine visceral leishmaniasis in the city of São Luís is still high, and the interruption of the activities of the Zoonosis Control Center seems to have contributed to this situation.

\section{References}

Abreu-Silva AL, Lima TB, De Macedo AA, Moraes-Júnior FJ, Dias EL, Batista ZS, et al. Soroprevalência, aspectos clínicos e bioquímicos da infecção por Leishmania em cães naturalmente infectados e fauna de flebotomíneos em uma área endêmica na Ilha de São Luís, Maranhão, Brasil. Rev Bras Parasitol Vet 2008; 17(Suppl 1): 197-203. PMid:20059848.

Almeida ABPF, Mendonça AJ, Sousa VRF. Prevalência e epidemiologia da leishmaniose visceral em cães e humanos, na cidade de Cuiabá, Mato Grosso, Brasil. Cienc Rural 2010; 40(7): 1610-1615. http://dx.doi.org/10.1590/S0103-84782010005000102.

Alvar J, Vélez ID, Bern C, Herrero M, Desjeux P, Cano J, et al. Leishmaniasis worldwide and global estimates of its incidence. PLoS One 2012; 7(5): e35671. http://dx.doi.org/10.1371/journal.pone.0035671. PMid:22693548.

Alvar J, Yactayo S, Bern C. Leishmaniasis and poverty. Trends Parasitol 2006; 22(12): 552-557. http://dx.doi.org/10.1016/j. pt.2006.09.004. PMid:17023215.

Alves WA, Bevilacqua PD. Reflexões sobre a qualidade do diagnóstico da leishmaniose visceral canina em inquéritos epidemiológicos: o caso da epidemia de Belo Horizonte, Minas Gerais, Brasil, 1993-1997. Cad Saude Publica 2004; 20(1): 259-265. http://dx.doi.org/10.1590/S0102-311X2004000100043. PMid:15029328.

Azevedo TS, Lorenz C, Chiaravalloti-Neto F. Risk mapping of visceral leishmaniasis in Brazil. Rev Soc Bras Med Trop 2019; 52: e20190240. http://dx.doi.org/10.1590/0037-8682-0240-2019. PMid:31778399.

Barbosa DS, Rocha AL, Santana AA, Souza CDSF, Dias RA, Costa-Júnior LM, et al. Soroprevalência e variáveis epidemiológicas associadas à Leishmaniose Visceral Canina em área endêmica no Município de São Luís, Maranhão, Brasil. Cienc Anim Bras 2010; 11(3): 653-659. http://dx.doi.org/10.5216/cab.v11i3.5933.

Barbosa DS. Distribuição espacial e definição de áreas prioritárias para vigilância da leishmaniose visceral no município de São Luís, Maranhão, Brasil [tese]. Rio de Janeiro: FIOCRUZ; 2011.

Belo VS, Werneck GL, Barbosa DS, Simões TC, Nascimento BWL, Silva ES, et al. Correction: factors associated with visceral leishmaniasis in the americas: a systematic review and meta-analysis. PLoS Neg/ Trop Dis 2013; 7(5). http://dx.doi.org/10.1371/ annotation/83856044-8747-4d93-9a1e-64f16bb60c07. 
Bigeli JG, Oliveira-Junior WP, Teles NMM. Diagnosis of Leishmania (Leishmania) chagasi infection in dogs and the relationship with environmental and sanitary aspects in the municipality of Palmas, state of Tocantins, Brazil. Rev Soc Bras Med Trop 2012; 45(1): 18-23. http://dx.doi.org/10.1590/S0037-86822012000100005. PMid:22370823.

Brasil. Ministério da Saúde. Manual de vigilância e controle da leishmaniose visceral. Brasília, DF: Ministério da Saúde; 2014.

Bruhn FRP, Morais MHF, Bruhn NCP, Cardoso DL, Ferreira F, Rocha CMBM. Human visceral leishmaniasis: factors associated with deaths in Belo Horizonte, Minas Gerais state, Brazil from 2006 to 2013. Epidemiol Infect 2018; 146(5): 565-570. http://dx.doi. org/10.1017/S0950268818000109. PMid:29463341.

Centro Panamericano de Zoonosis - CEPANZO. Procedimentos para estudios de prevalencia por muestro. Buenos Aires; 1979.

Costa AP, Costa FB, Soares HS, Ramirez DG, Carvalho Araújo A, Ferreira JIGS, et al. Environmental factors and ecosystems associated with canine visceral leishmaniasis in Northeastern Brazil. Vector Borne Zoonotic Dis 2015; 15(12): 765-774. http:// dx.doi.org/10.1089/vbz.2015.1866. PMid:26684524.

Costa JML, Viana GMC, Saldanha ACR, Nascimento MDSB, Alvim AC, Burattini MN, et al. Leishmaniose visceral no estado do Maranhão, Brasil: a evolução de uma epidemia. Cad Saude Publica 1995; 11(2): 321-324. http://dx.doi.org/10.1590/S0102311X1995000200016. PMid:14528339.

Dantas-Torres F, Brito ME, Brandão-Filho SP. Seroepidemiological survey on canine leishmaniasis among dogs from an urban area of Brazil. Vet Parasito/ 2006; 140(1-2): 54-60. http://dx.doi.org/10.1016/j.vetpar.2006.03.008. PMid:16621286.

Figueiredo MJFM, Souza NF, Figuereido HF, Meneses AMC, Silva E Fo, Nascimento GG. Fatores de risco e classificação clínica associados à soropositividade para leishmaniose visceral canina. Cienc Anim Bras 2014; 15(1): 102-106. http://dx.doi.org/10.5216/ cab.v15i1.25097.

Foglia Manzillo V, Di Muccio T, Cappiello S, Scalone A, Paparcone R, Fiorentino E, et al. Prospective study on the incidence and progression of clinical signs in naïve dogs naturally infected by Leishmania infantum. PLoS Neg/ Trop Dis 2013; 7(5): e2225. http:// dx.doi.org/10.1371/journal.pntd.0002225. PMid:23675551.

França-Silva JC, Costa RT, Siqueira AM, Machado-Coelho GLL, Costa CA, Mayrink W, et al. Epidemiology of canine visceral leishmaniasis in the endemic area of Montes Claros municipality, Minas Gerais State, Brazil. Vet Parasito/ 2003; 111(2-3): 161-173. http://dx.doi.org/10.1016/S0304-4017(02)00351-5. PMid:12531292.

Fundação Nacional de Saúde - FUNASA. Diretrizes para projetos físicos de unidades de controle de zoonoses e fatores biológicos de risco. Brasília, DF: FUNASA; 2003.

Instituto Brasileiro de Geografia e Estatística - IBGE. São Luís [online]. Rio de Janeiro: IBGE; 2018 [cited 2019 Feb 1]. Available from: http://cidades.ibge.gov.br/xtras/perfil.php?codmun=211130

Julião FS, Souza BMPS, Freitas DS, Oliveira LS, Larangeira DF, Dias-Lima AG, et al. Investigação de áreas de risco como metodologia complementar ao controle da leishmaniose visceral canina. Pesq Vet Bras 2007; 27(8): 319-324. http://dx.doi.org/10.1590/S0100736X2007000800001.

Lindoso JAL, Moreira CHV, Cunha MA, Queiroz IT. Visceral leishmaniasis and HIV coinfection: current perspectives. HIV AIDS (AuckI) 2018; 10: 193-201. http://dx.doi.org/10.2147/HIV.S143929. PMid:30410407.

Madalosso G, Fortaleza CM, Ribeiro AF, Cruz LL, Nogueira PA, Lindoso JAL. American visceral leishmaniasis: factors associated with lethality in the state of São Paulo, Brazil. J Trop Med 2012; 2012: 281572. http://dx.doi.org/10.1155/2012/281572. PMid:23024661.

Manna L, Corso R, Galiero G, Cerrone A, Muzj P, Gravino AE. Long-term follow-up of dogs with leishmaniosis treated with meglumine antimoniate plus allopurinol versus miltefosine plus allopurinol. Parasit Vectors 2015; 8(1): 289. http://dx.doi. org/10.1186/s13071-015-0896-0. PMid:26017164.

Marcondes M, Rossi CN. Leishmaniose visceral no Brasil. Braz J Vet Res Anim Sci 2013; 50(5): 341-352. http://dx.doi.org/10.11606/ issn.2318-3659.v50i5p341-352.

Margonari C, Freitas CR, Ribeiro RC, Moura ACM, Timbó M, Gripp AH, et al. Epidemiology of visceral leishmaniasis through spatial analysis, in Belo Horizonte municipality, state of Minas Gerais, Brazil. Mem Inst Oswaldo Cruz 2006; 101(1): 31-38. http://dx.doi. org/10.1590/S0074-02762006000100007. PMid:16699707.

Miranda S, Roura X, Picado A, Ferrer L, Ramis A. Characterization of sex, age, and breed for a population of canine leishmaniosis diseased dogs. Res Vet Sci 2008; 85(1): 35-38. http://dx.doi.org/10.1016/j.rvsc.2007.09.003. PMid:17942128.

Paltrinieri S, Solano-Gallego L, Fondati A, Lubas G, Gradoni L, Castagnaro M, et al. Guidelines for diagnosis and clinical classification of leishmaniasis in dogs. J Am Vet Med Assoc 2010; 36(11): 1184-1191. http://dx.doi.org/10.2460/javma.236.11.1184. PMid:20513195.

Silva AR, Tauil PL, Cavalcante MNS, Medeiros MN, Pires BN, Gonçalves EDGDR. Situação epidemiológica da leishmaniose visceral, na Ilha de São Luís, Estado do Maranhão. Rev Soc Bras Med Trop 2008; 41(4): 358-364. http://dx.doi.org/10.1590/S003786822008000400007. PMid:18853007. 
Silva KR, Mendonça VRR, Silva KM, Nascimento LFM, Mendes-Sousa AF, Pinho FA, et al. Scoring clinical signs can help diagnose canine visceral leishmaniasis in a highly endemic area in Brazil. Mem Inst Oswaldo Cruz 2017; 112(1): 53-62. http://dx.doi. org/10.1590/0074-02760160305. PMid:28076469.

Sistema de Informação de Agravos de Notificação - SINAN. [online]. Brasília, DF: SINAN; 2018 [cited 2019 Aug 17]. Available from: http://portalarquivos2.saude.gov.br/images/pdf/2018/novembro/12/LV-Coef-Incidencia.pdf

Sistema de Informação de Agravos de Notificação - SINAN. [online]. Brasília, DF: SINAN; 2019a [cited 2019 Aug 17]. Available from: http://tabnet.datasus.gov.br/cgi/tabcgi.exe?sinannet/cnv/leishvbr.def

Sistema de Informação de Agravos de Notificação - SINAN. [online]. Brasília, DF: SINAN; 2019b [cited 2019 Aug 17]. Available from: http://tabnet.datasus.gov.br/cgi/tabcgi.exe?sinannet/cnv/leishvmg.def

Sistema de Informação de Agravos de Notificação - SINAN. [online]. Brasília, DF: SINAN; 2019c [cited 2019 Aug 17]. Available from: http://tabnet.datasus.gov.br/cgi/tabcgi.exe?sinannet/cnv/leishvma.def

Toscano CP, Rossi CN, Ribeiro VM, Laurenti MD, Larsson CE. Caracterização clínica e epidemiológica das leishmanioses em cães no Estado de São Paulo. Braz J Vet Res Anim Sci 2013; 50(2): 121-128. http://dx.doi.org/10.11606/issn.2318-3659.v50i2p121-128.

Trotz-Williams L, Gradoni L. Disease risks for the travelling pet: leishmaniasis. In Pract 2003; 25(4): 190-197. http://dx.doi. org/10.1136/inpract.25.4.190.

Vigilato M. Distribuição espacial da leishmaniose visceral canina e humana no município de Birigui-SP [dissertação]. São Paulo: Universidade Estadual Paulista "Júlio de Mesquita Filho"; 2004.

Werneck GL. Controle da leishmaniose visceral no Brasil: o fim de um ciclo? Cad Saude Publica 2016; 32(6): eED010616. http:// dx.doi.org/10.1590/0102-311X00ED010616. PMid:27333133. 